\title{
MORA LI IDENTITET BITI NUŽAN?
}

\author{
Marko Jurjako, Zdenka Brzović
}

Sveučilište u Rijeci, Filozofski fakultet, Hrvatska

mjurjako@ffri.uniri.hr; zdenka@uniri.hr

Primljeno: 23. 4. 2021.

U radu se nudi opis konteksta unutar kojeg je formuliran poznati dokaz za nužnost identiteta. Iznosi se formalni prikaz ovog dokaza kako ga je formulirao poznati filozof i logičar Saul Kripke. Također se razmatra gledište filozofa Allana Gibbarda koji nasuprot Kripkeu brani tvrdnju da neki iskazi identiteta mogu biti kontingentni. Osnovni cilj rada je upoznati domaćeg čitatelja s formalnim aspektom rasprave o nužnosti identiteta te dati kratki pregled konteksta unutar kojeg su formulirani argumenti za (ne)nužnost identiteta.

Ključne riječi: Allan Gibbard, dokaz nužnosti identiteta, kontingentni identitet, numerički identitet, Saul Kripke

\section{Uvod*}

U radu približavamo čitatelju kontekst unutar kojeg je formuliran poznati dokaz prema kojemu slijedi da ako su dvije stvari identične onda one moraju biti nužno identične. Izlažemo formalni prikaz ovog dokaza kako ga je formulirao poznati filozof i logičar Saul Kripke (1971, 1979). Zatim razmatramo gledište filozofa Allana Gibbarda (1975) koji nasuprot Kripkeu brani gledište da neki iskazi identiteta mogu biti kontingentni.

*Htjeli bismo se zahvaliti Luci Malatestiju i Boranu Berčiću na komentiranju ranije verzije ovog rada. Također, zahvale idu dvama recenzentima za časopis Metodički ogledi na temelju čijih komentara je rad značajno poboljšan. Izvorna verzija članka nastala je u sklopu rada na projektu Identitet: kriteriji sinkronog i dijakronog identiteta (Sveučilište u Rijeci). MJ zahvaljuje se na financijskoj potpori koju dobiva u sklopu rada na sljedećim projektima: projekt RAD, HRZZ, IP-2018-01-3518; projekt HIRe, HRZZ, UIP-2017-05-4308; projekt KUBIM, Sveučilište u Rijeci, uniri-human-18-265. ZB zahvaljuje se na financijskoj potpori koju dobiva u sklopu rada na projektima: projekt ThUMB, HRZZ, IP-2018-01-3378; projekt KUBIM, Sveučilište u Rijeci, uniri-human-18-265. 
Dva su glavna cilja ovog rada. Prvi cilj je upoznati domaćeg čitatelja s formalnim aspektom rasprave o nužnosti identiteta te dati kratki pregled konteksta unutar kojeg su formulirani argumenti za (ne)nužnost identiteta. Drugi cilj je tu raspravu prikazati na način koji će biti dostupan studenima i/ili učenicima koji posjeduju razumijevanje logike prvog reda te nastavnicima dati podlogu za pripremu nastavne jedinice na temu nužnosti identiteta. Stoga, prije pregleda same rasprave u ostatku uvoda prvo ćemo istaknuti filozofsku važnost razmišljanja o ovom pitanju te točnije delimitirati pojam identiteta o kojem ćemo govoriti u ostatku teksta.

Pojam identiteta igra fundamentalnu ulogu u našim pojmovnim shemama kojima opisujemo i objašnjavamo svijet te stvari i ljude unutar njega. $O$ identitetu razmišljamo kada se pitamo što je to točno što nas čini nama samima? Jesmo li mi ista osoba koja smo bili kada smo se rodili ili se kroz vrijeme mijenjamo tako da postajemo neka druga osoba? Ako smatramo da postoji neka zajednička srž kakvi smo sada i kakvi smo bili nekad možemo se pitati što točno definira tu srž. Jesmo li mi mogli biti mi čak i da smo se rodili u drugo vrijeme od drugih roditelja, posjedujuću drugu genetsku strukturu? Ova pitanja se obično svrstavaju u raspravu o tome što čini osobni identitet (Berčić, 2017).

Pitanja identiteta također se odnose na partikularne kvalitete ili obilježja koje sačinjavaju naš osobni identitet. Ovdje se možemo pitati što određuje naše identitete poput činjenica da pripadamo određenim društvenim klasama, spolnim orijentacijama, društvenim ulogama koje okupiramo i tome slično. Imaju li oni neke esencijalne karakteristike ili ih izgrađujemo kroz osobni razvoj, društveni odgoj ili nešto treće? Ova pitanja odnose se na ono što se može nazvati kvalitativnim aspektom pojma 'identitet' jer se radi o specifičnim svojstvima koji nas čine sličnima ili različitima od drugih ljudi. Naravno, i o drugim stvarima možemo govoriti u terminima kvalitativnog identiteta. Na primjer, dvije granitne stijene mogu biti kvalitativno slične jer dijele obilježja poput boje koja su tipična za granit. Također se mogu kvalitativno razlikovati, na primjer, prema svojem obliku jer na izgled stijene utječu prirodni procesi.

Filozofska pitanja o identitetu mogu se postaviti i općenitije na način da se pitamo što čini neku stvar onime što ona jest, a ne nekom drugom stvari. Pitanja o identitetu u ovom se smislu odnose na ono 
što se naziva numeričkim identitetom. Numerički identitet podrazumijeva kvalitativni identitet te se odnosi na relaciju koju predmet ima prema samom sebi. Koristi se izraz 'numerički identitet' jer se njime nastoji zahvatiti ideja identiteta koja nam omogućava da individuiramo i prebrojavamo stvari (usp. Noonan i Curtis, 2018). Ako su stvari $x$ i $y$ numerički identične, onda govorimo o jednoj stvari te kada bismo prebrojavali stvari onda bismo $x$ i $y$ brojali samo jednom. Ako $x$ i $y$ nisu numerički identične stvari onda bismo ih pri brojanju naveli zasebno. U ovom radu bavimo se upravo numeričkim pojmom identiteta te ćemo razmotriti je li identitet u tom smislu nužan.

Kada se pitamo je li iskaz nužno istinit, tada se pod time podrazumijeva pitanje je li taj iskaz istinit u svim mogućim svjetovima. $U$ logici se mogući svjetovi shvaćaju kao maksimalno konzistentni i potpuni skupovi iskaza ili propozicija. Skup propozicija je maksimalno konzistentan kada se u njemu ne nalaze kontradikcije. Skup propozicija je maksimalno potpun kada za svaki par kontradiktornih propozicija $p$ i ne- $p$ taj skup sadrži $p$ ili njegovu negaciju, dakle ne-p. Intuitivno, mogući svijet može se shvatiti kao potpuni opis svijeta ili toga kako je svijet mogao izgledati. Na primjer, u našem aktualnom svijetu Hrvatska je na Olimpijskim igrama koje su se održale 2021. godine osvojila više od 10 zlatnih medalja. Međutim, moglo se dogoditi da je osvojila manje medalja. Tada zamišljamo mogući svijet koji je identičan našem aktualnom svijetu u svim aspektima, osim što Hrvatska 2021. nije osvojila 10 zlatnih medalja na Olimpijskim igrama. Možemo zamisliti i radikalno drugačije moguće svjetove. U našem aktualnom svijetu kroz fizičke događaje poput Velikog praska nastao je nama poznati svemir uključujući i planet Zemlju. Međutim, možemo zamisliti da nikada nije došlo do Velikog praska. U tom slučaju zamišljamo mogući svijet u kojem ne bi postojala Zemlja niti svemir u našem smislu riječi.

Pojam mogućeg svijeta koristan je za razmišljanje o nužnim i kontingentnim istinama. Nužno istiniti iskazi bili bi oni koji su istiniti u svim mogućim svjetovima. Paradigmatski primjer nužnih istina su matematički teoremi. Na primjer, da je $2+2=4$ smatra se iskazom koji je istinit u svim mogućim svjetovima. Drugim riječima, negacija tog iskaza bila bi kontradikcija te u tom smislu ne postoji mogući svijet u kojemu dva plus dva ne bi bilo četiri. Kontingentni iskazi, s druge strane, mogu biti istiniti u nekim mogućim svjetovima, a neistiniti u drugima. 
Na primjer, u našem aktualnom svijetu, na američkim predsjedničkim izborima 2020. godine pobijedio je Joe Biden. No, možemo zamisliti da postoji mogući svijet u kojem je na tim izborima ponovo pobijedio Donald Trump. U tom smislu, iskaz da je Biden pobijedio na predsjedničkim izborima 2020. godine predstavlja kontingentnu istinu. Pitanje koje ćemo razmotriti odnosi se na to jesu li istiniti iskazi numeričkog identiteta sličniji matematičkim teoremima ili ponekad mogu biti kontingentni poput iskaza da je Joe Biden pobijedio na predsjedničkim izborima.

U numeričkom smislu pojam identitet je naizgled jednostavan (usp. Lowe, 2002, pogl. 2). Čini se trivijalnim reći da je svaka stvar identična samoj sebi. Međutim, unatoč ovom truizmu, filozofi su nastojali pokazati kakve dalekosežne posljedice on može imati za naše poimanje stvarnosti i nas samih. U tom pogledu, razmotrit ćemo poznati argument da se um i njegova svojstva ne mogu svesti na fizičku materiju i njezina svojstva.

Smatra se da je njemački filozof Gottfried Leibniz dao osnovnu karakterizaciju numeričkog pojma identiteta (Magidor, 2011). Leibnizov zakon uključuje dva principa. Prema principu nerazlučivosti identiteta ako je predmet $a$ identičan predmetu $b$, onda oni moraju imati sva ista svojstva. Prema principu identiteta nerazlučivih ako $a$ ima sva ista svojstva kao i $b$, onda su oni istovjetni predmet.

Na temelju ovog principa poznati francuski filozof René Descartes (2015) argumentirao je da ako um i tijelo imaju različita svojstva, onda um ne može biti tjelesna stvar. Jedan od argumenata koje je ponudio može se formulirati na sljedeći način:

A. Tijelo je vrsta stvari koja se može dijeliti (na primjer, tijelo se može raskomadati u dijelove).

B. Um nije vrsta stvari koja se može dijeliti (drugim riječima, nije vrsta stvari koja ima dijelove).

C. Stoga, um nije isto što i tijelo.

Argumentom se tvrdi da s obzirom na to da um i tijelo imaju barem jedno različito svojstvo, onda prema Leibnizovom principu ne mogu biti ista stvar.

Suvremenu inačicu spomenutog kartezijanskog (lat. Cartesius = Descartes) zaključivanja razvio je Saul Kripke. Na temelju tvrdnje da 
iskazi identiteta predstavljaju nužne istine, argumentirao je da se mentalna stanja ne mogu reducirati na fizička stanja mozga (Kripke, 1997; za raspravu, usp. Pećnjak i Špiljak, 2014, 85-89). Njegova varijanta argumenta može se formulirati na sljedeći način:

1. Ako su svjesna mentalna stanja identična određenim fizičkim stanjima mozga, onda to mora biti tako u svakom mogućem svijetu.

2. U nekim mogućim svjetovima svjesna mentalna stanja nisu identična fizičkim stanjima mozga.

3. Dakle, svjesna mentalna stanja nisu identična fizičkim stanjima mozga (usp. Berčić, 2012, 180).

Prvom premisom izražava se jedna instanca principa da je identitet nužan. U ovom kontekstu tvrdi se da ako su svjesna mentalna stanja identična nekim fizičkim stanjima mozga, onda je nužno da su svjesna mentalna stanja identična tim stanjima mozga. Drugom se premisom tvrdi da postoji barem jedan mogući svijet gdje mentalna stanja nisu identična stanjima mozga. Kako bi se ustanovila ta premisa, obično se u filozofskoj literaturi autori pozivaju na pojam filozofskog zombija (usp. npr. Berčić, 2012, 179-181; Pećnjak i Janović, 2016). Filozofski zombi, za razliku od holivudskog, je osoba koja je u svim fizičkim aspektima poput nas (isto izgleda, hoda, jede, pije, kada ga se udari radi grimase, jauče i tome slično), međutim ne posjeduje svjesna mentalna stanja. Da se izrazimo metaforički, filozofskom zombiju, unatoč tome što je fizički i bihevioralno identičan običnim ljudima, svjetla svjesnosti su iznutra ugašena. Ako možemo zamisliti da postoje zombiji u tom smislu, onda iz 1. i 2. slijedi da svjesna mentalna stanja ne mogu biti identična fizičkim stanjima mozga (usp. Berčić, 2012, 179-187).

U literaturi iz filozofije uma obično se podrazumijeva istinitost prve premise te se vode žustre rasprave oko toga jesu li filozofski zombiji mogući ili nisu (za pristupačan pregled rasprave, vidi Berčić, 2012, pogl. »Um«). Međutim, najčešće se ne ulazi u prikazivanje dokaza zašto vrijedi tvrdnja o nužnosti identiteta koja se nalazi u podlozi premise 1. Ako se spominje ta premisa, onda se ona obično opravdava intuitivnim razmatranjima o tome što znači da je neka stvar identična samoj sebi (usp. npr. Pećnjak i Janović, 2016, 123).

Nakon što smo razmotrili neke od važnijih filozofskih posljedica tvrdnje da je identitet nužan, u nastavku rada pobliže ćemo razmotriti 
što se zapravo tvrdi načelom da su istiniti iskazi identiteta nužne istine te koji bi bili razlozi za prihvaćanje te tvrdnje.

Ostatak rada strukturiran je na sljedeći način. U drugom odjeljku prikazan je Kripkeov dokaz nužnosti identiteta. U trećem odjeljku kratko razmatramo povijest dokaza nužnosti identiteta. U četvrtom odjeljku bavimo se Kripkeovom obranom nužnosti identiteta od prigovora kojima se nastoji pokazati kako svi iskazi identiteta ne pretendiraju biti nužne istine. Konačno, u petom odjeljku razmatramo reakcije na Kripkeovo gledište prema kojima njegova obrana nužnosti identiteta nije zadovoljavajuća. Naime, neki autori imaju snažnu intuiciju da su neki iskazi identiteta kontingentni. Usredotočit ćemo se na poznatu teoriju kontingentnog identiteta koju nudi Allan Gibbard. U šestom odjeljku dajemo zaključna razmatranja.

\section{Dokaz nužnosti identiteta}

Kripke nudi kratak dokaz za nužnost identiteta na početku svog poznatog članka »Identity and necessity« (usp. Kripke, 1979).' Argument se može predstaviti s dvije premise. Prvom premisom se izražava nužnost tvrdnje da je svaki predmet identičan samom sebi.

(1) $\forall x \square(x=x)$

Znak »口« (kvadrat ili kutija) u modalnoj logici označava nužnost. Znak » « (dijamant) označava mogućnost koja se u odnosu na nužnost definira na sljedeći način: $\diamond p \leftrightarrow \neg \square \neg p$. Premisom (1) se tvrdi da je za svaki predmet $x$ nužno da je $x$ identičan ili istovjetan samom sebi. Premisa (1) se često opravdava intuitivnim razmatranjima ili se uzima zdravo za gotovo. Na primjer Kripke jednostavno izjavljuje »svaki predmet je zasigurno samo-identičan « (Kripke, 1979, 163 kurziv dodan). Dakle, jednostavno se smatra istinitom tvrdnja da su svi predmeti identični samima sebi te da ne mogu biti neki drugi predmet.

Druga premisa može se izraziti na sljedeći način:

(2) $\forall x \forall y((x=y) \rightarrow(\square(x=x) \rightarrow \square(x=y)))$

\footnotetext{
${ }^{1}$ Članak je izvorno objavljen u Kripke (1971). Hrvatski prijevod se nalazi u Kripke (1987).
} 
Kripke $(1979,163)$ opravdava prihvaćanje ove premise na temelju Leibnizovog zakona, tj. varijanti koja se odnosi na nerazlučivost identiteta. Ona se može formulirati na sljedeći način:

(NI) $\forall x \forall y((x=y) \rightarrow(\mathrm{F} x \rightarrow \mathrm{F} y))$

Ovdje F označava proizvoljni predikat koji obilježava neki predmet. Iskazom se općenito tvrdi da za svaki predmet $x$ i za svaki predmet $y$, ako $x$ i $y$ referiraju na isti predmet, onda što god je istinito o $x$ također je istinito o $y$. Drugim riječima, ako su predmeti identični, onda imaju ista svojstva, tj. obilježavaju ih isti predikati. Prihvaćanje premise (2) možemo opravdati kao jednu instancu principa (NI) na sljedeći način. Kripke pretpostavlja da jedno od svojstava koje predmeti mogu imati jest da su nužno identični samima sebi. U vokabularu modalne logike prvog reda ta misao se formalno može zahvatiti tako da predikat $\mathrm{F} x$ zamijenimo s izrazom $\gg \square(x=x)$ «. Dakle, predikat $\mathrm{F}$ u ovom slučaju obilježava svojstvo samoidentičnosti. Slično vrijedi i u slučaju predikata $\mathrm{F}(y)$. Budući da pretpostavljamo da $(x=y)$, onda slijedi da ako $x$ ima svojstvo biti nužno identičan s $x$, onda $y$ također ima svojstvo biti nužno identičan s $x$. Ovo zaključivanje nas opravdava da predikat $\mathrm{F} y$ zamijenimo s izrazom $\gg \square(x=y)$ « te time dobivamo premisu (2).

Iz ovih naizgled nekontroverznih premisa slijedi značajan zaključak da je identitet nužan. Možemo ga izraziti na sljedeći način:

(K) $\forall x \forall y((x=y) \rightarrow \square(x=y))$

U nastavku slijedi derivacija ove konkluzije. Domena rasprave su svi mogući predmeti.

(1) $\mid \forall x \square(x=x)$

(2) $\forall x \forall y((x=y) \rightarrow(\square(x=x) \rightarrow \square(x=y)))$

(4)

(5)
Nužnost samo-identiteta

Instanca nerazlučivosti identiteta

Uvođenje arbitrarnog imena $a$

Uvođenje arbitrarnog imena $b$

Uvođenje pretpostavke $a=b$

$\forall$ eliminacija (2)

$\forall$ eliminacija (4) 


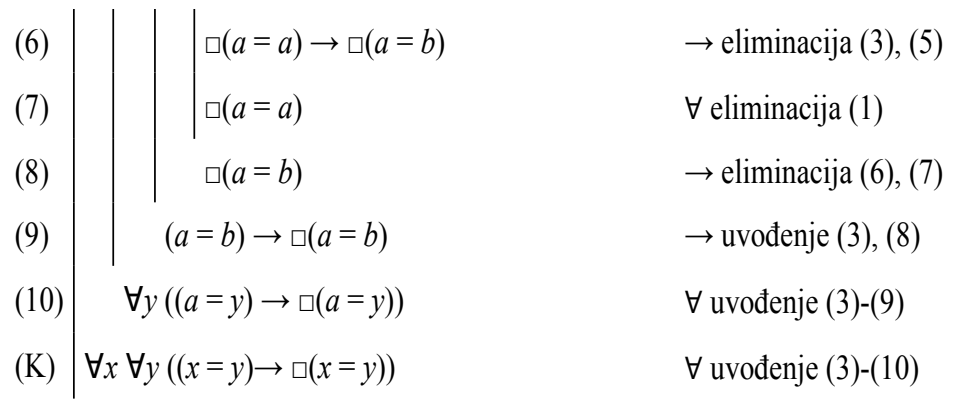

Ovdje imamo dokaz da ako su dvije stvari identične, onda one moraju biti identične u svim mogućim svjetovima. Drugim riječima, stvari ne mogu biti samo kontingentno identične.

\section{Povijest i kontroverze vezane \\ za dokaz nužnosti identiteta}

Kripke (1979) ovu varijantu dokaza pripisuje Davidu Wigginsu (1965). Međutim, derivaciju zaključka da je svaki identitet nužan već je ranije dala Ruth Barcan Marcus u svojem radu »Identity of individuals in a strict functional calculus of second order « (1947). To je bio njezin treći rad iz serije članaka koji su objavljeni u časopisu The Journal of Symbolic Logic (usp. Burgess, 2014, 1568). No priča tu ne staje. Čini se da u ovoj jednostavnijoj formi, dokaz prvi navodi Willard van Orman Quine (Burgess, 2014, 1570). To je zanimljiv podatak budući da je Quine bio poznat kao žestoki protivnik kvantificirane modalne logike (usp. Quine, 1961). Prema Johnu Burgessu $(1947,1570)$ ono što objašnjava ovaj slijed događaja jest činjenica da je Quine izvorni recenzent članaka koje je Barcan Marcus poslala u časopis The Journal of Symbolic Logic te je prvi shvatio da se za derivaciju nužnosti identiteta može dati jednostavniji dokaz nego onaj koji je ponudila Barcan Marcus.

Obično se smatra da uvjerljivost dokaza za nužnost identiteta ovisi o uvjerljivosti prve premise (Burgess, 2014, 1572). Kripke je jednostavno postulira te navodi da se modalni operatori u dokazu trebaju interpretirati kao de re (lat. o stvari). Prema ovom shvaćanju modalnost označava metafizičku ili ontološku modalnost koja se odnosi na prirodu predmeta o kojima govorimo, a ne modalnost koja bi se odnosila na iskaze ili de dicto (lat. o onome što je rečeno) modalnost. U modalnoj 
logici razlika između de re i de dicto modalnosti se pokazuje s mjestom modalnog operatora u rečenici. Rečenica $» \exists x \square \mathrm{F} x \ll$ izražava de re modalnost jer se njome tvrdi da neki predmet nužno ima svojstvo F. Možemo reći da se time tvrdi da je F esencijalno svojstvo predmeta $x$. Rečenica $\gg \square \exists x$ Fx« izražava de dicto modalnost jer se njome tvrdi da cijela rečenica izražava nužnu istinu, naime da je nužno da postoji neki predmet koji ima svojstvo F. Kripke navodi da metafizičko de re shvaćanje modalnosti omogućuje izvođenje konkluzije (K) (usp. Kripke, 1979, 480). Na primjer, vidjeli smo da ono omogućuje izvođenje premise

(2) $\forall x \forall y((x=y) \rightarrow(\square(x=x) \rightarrow \square(x=y)))$

iz principa

(NI) $\forall x \forall y((x=y) \rightarrow(\mathrm{F} x \rightarrow \mathrm{F} y))$

tako što smo pretpostavili da predikat $F$ može referirati na bilo koje svojstvo uključujući i svojstvo biti nužno identičan nekom predmetu $(\square(x=x))$. Upravo se ovdje pretpostavlja de re čitanje modalnosti jer pretpostavljamo da se modalni operator u premisama (1) i (2) shvaća kao da izražava svojstvo da je određeni predmet nužno identičan samom sebi.

Vidjeli smo da Kripke ne daje direktan dokaz za premisu (1) već je umjesto toga samo pretpostavlja. Možemo se pitati zašto je tome tako? Ovo pitanje se nameće jer u vrijeme kada Kripke piše svoj rad već postoji barem jedan udžbenik iz logike koji daje prikaz dokaza za nužnost identiteta te uključuje derivaciju premise (1) (usp. Burgess, 2014, 1573). Međutim, kao što ćemo vidjeti, ta derivacija pretpostavlja valjanost Barcan shema koje imaju kontroverzan status unutar nekih rasprava u metafizici. Barcan sheme se tako nazivaju u čast Barcan Marcus te se sastoje od Barcan sheme i obratne Barcan sheme.

Barcan Shema (BS): $\quad$ Obratna Barcan Shema (OBS):

$$
\text { (11) } \forall x \square \Phi \rightarrow \square \forall x \Phi \quad \text { (12) } \square \forall x \Phi \rightarrow \forall x \square \Phi
$$

Treba primijetiti da Barcan sheme, budući da su logičke sheme, izražavaju beskonačan broj mogućih formula. Na primjer, jedna instanca OBS-a je rečenica $\square \forall x$ F $\rightarrow \forall x \square \mathrm{F} x$, gdje smo shematsko slovo $\Phi$ koje predstavlja predikate zamijenili s konkretnim predikatom $F x$. 
Značajnost BS-a i OBS-a sastoji se u tome što daju pravila za primjenu kvantifikatora u određenim modalnim kontekstima. Štoviše, njima se tvrdi da se u određenim modalnim kontekstima kvantifikatori i modalni operatori mogu zamjenjivati, tj. da su neke de re i de dicto kvantificirane rečenice ekvivalentne (usp. Ben-Yami, 2020). U nastavku ćemo konkretnije vidjeti kako nam OBS omogućuje da izvedemo zaključak iz $\forall x(x=x)$ na $\forall x \square(x=x)$ (usp. Burgess, 2014, 1573).

\begin{tabular}{l|ll} 
(13) & $\forall x(x=x)$ & Premisa \\
(14) & $\square \forall x(x=x)$ & Pravilo necesitacije (13) \\
(15) & $\square \forall x(x=x) \rightarrow \forall x \square(x=x)$ & Instanca Obratne Barcan Sheme \\
[(1)] & $\forall x \square(x=x)$ & $\rightarrow$ eliminacija (14), (15)
\end{tabular}

Premisa (13) izražava univerzalni zakon identiteta te se smatra teoremom u logici prvog reda. (14) slijedi iz (13) na temelju pravila necesitacije iz modalne logike. Pravilo necesitacije navodi da ako je rečenica $A$ logički teorem, onda smijemo zaključiti da je rečenica $A$ nužno istinita. ${ }^{2}$ Premisa (15) je instanca Obratne Barcan Sheme kada $\Phi$ zamijenimo predikatom $(x=x)$. Premisa (1) slijedi iz (14) i (15) primjenom pravila za eliminaciju kondicionala.

Međutim, mnogi smatraju da su Barcan sheme podložne protuprimjerima (za raspravu usp. Ben-Yami, 2020; Williamson, 2013, pogl. 2). To je možda jedan od razloga zašto Kripke koristi dokaz za nužnost identiteta koji ne pretpostavlja Barcan sheme (usp. Burgess, 2014, 1573). Protuprimjeri postaju jasniji kada u obzir uzmemo formalne ekvivalente od BS i OBS:

$$
\begin{aligned}
& \text { (BS') } \diamond \exists x \Phi \rightarrow \exists x \diamond \Phi \leftrightarrow \forall x \square \Phi \rightarrow \square \forall x \Phi \\
& \text { (OBS') } \exists x \diamond \Phi \rightarrow \diamond \exists x \Phi \leftrightarrow \square \forall x \Phi \rightarrow \forall x \square \Phi^{3}
\end{aligned}
$$

\footnotetext{
${ }^{2}$ Pravilo necesitacije: Ako $\vdash A$, onda $\vdash \square A$.

${ }^{3}$ Formalnu ekvivalentnost ćemo objasniti na primjeru (BS'). Uzmimo na primjer iskaz $\diamond \exists x \mathrm{~F} x \rightarrow \exists x \diamond \mathrm{F} x$ kao instancu BS'. Stavimo ga u kontrapoziciju čime dobivamo (BS") $\neg \exists x$ $\diamond \mathrm{F} x \rightarrow \neg \diamond \exists x$ F $x$. Iz definicije egzistencijalnog kvantifikatora znamo da je $\exists x \Phi$ ekvivalentno $\neg \forall x \neg \Phi$. Također iz definicije modalnih operatora znamo da je $\diamond \Phi$ ekvivalentno $\neg \square \neg \Phi$. Primjena ekvivalentnosti kvantifikatora na (BS") u prvom koraku omogućuje transformaciju:
} 
Protuprimjer za (BS') može biti sljedeći (usp. Williamson, 2013, 35). Uzmimo da F znači »biti dijete Johna F. Kennedya i Marilyn Monroe«, pod pretpostavkom da Kennedy i Monroe nisu imali djece. Ipak, metafizički je moguće da su Kennedy i Monroe imali dijete $(\diamond \exists x \mathrm{~F} x)$. $\mathrm{Na}$ temelju (BS') slijedi da stvarno postoji dijete koje je moglo biti od Kennedyja i Monroe $(\exists x \diamond \mathrm{F} x)$. Međutim, nije jasno koje bi to bilo dijete. Štoviše, mnogi smatraju da je esencijalno svojstvo svakog čovjeka da ima roditelje koje ima, tj. da se razvio na temelju genetskog materijala svojih aktualnih roditelja (usp. npr. Kripke, 1997, 98-99). Ako je ta pretpostavka uvjerljiva, onda se čini da zapravo ne postoji dijete za koje je moguće da je od Kennedyja i Monroe ( $\neg \exists \vee \mathrm{F} x)$. Time smo došli do negacije konzekvensa instance BS'-a.

(OBS') je također podložan protuprimjerima (usp. Williamson, 2013, 37-38). Pretpostavimo da F znači »ništa nije $x \ll(\neg \exists y(x=y))$. Razumno je za pretpostaviti da je naš svijet mogao sadržavati manje stvari nego što ih zapravo sadržava. Na primjer, planina Učka je mogla ne postojati. U tom smislu, čini se da postoji takva stvar (npr. Učka) za koju je moguće da ništa nije ta stvar, tj. za koju je moguće da ne postoji $(\exists x \diamond \neg \exists y(x=y))$. Međutim, (OBS') nam sada dopušta da zaključimo da je moguće da postoji stvar koja je takva da ništa nije ta stvar $(\diamond \exists x$ $\neg \exists y(x=y))$. Drugim riječima, moguće je da postoji stvar koja ničemu nije identična. Međutim, u logici prvog reda iskaz $\exists x \neg \exists y(x=y)$ nije konzistentan. Naime, ako Učka postoji $(\exists y(U c ̌ k a=y))$, onda prema pravilu za uvođenje egzistencijalnog kvantifikatora slijedi da postoji neki predmet s kojim je Učka identična $(\exists x \exists y(x=y))$. Dakle, čini se da suprotno prvotnoj pretpostavci zapravo nije moguće da postoji predmet koji nije identičan s nekom stvari $(\neg \diamond \exists x \neg \exists y(x=y))$. Time smo došli do negacije konzekvensa instance OBS'-a.

\section{Obrana nužnosti identiteta}

Kao što smo vidjeli Kripke ne brani premisu (1) na temelju logičkog dokaza. Nasuprot tome, brani premisu (1) razmatrajući prigovore

\footnotetext{
$\forall x \neg \vee \mathrm{F} x \rightarrow \neg \diamond \neg \forall x \neg \mathrm{F} x$. Ekvivalentnost modalnih operatora u drugom koraku omogućuje transformaciju: $\forall x \neg \neg \mathrm{F} x \rightarrow \square \forall x \neg \mathrm{F} x$. Time dobivamo jednu instancu BS-a. Koristeći isti način zaključivanja može se pokazati ekvivalentnost iskazana u OBS'.
} 
kojima se nastoji pokazati da svi iskazi identiteta ne pretendiraju biti nužne istine. Prema tome Kripke razmatra tri vrste iskaza o identitetu i nastoji pokazati na koji način oni mogu predstavljati kontingentne istine, a da to ne predstavlja problem za premisu (1) i u konačnici konkluziju (K).

U vrijeme kada se Kripke bavio ovom temom bilo je uobičajeno tvrditi da je moguće da su stvari identične, ali samo u kontingentom smislu (usp. npr. Wiggins, 1965). Na primjer, u filozofiji uma neki autori su $\mathrm{u}$ to vrijeme branili teoriju identiteta tipova. Prema toj teoriji mentalna stanja su identična stanjima mozga (usp. npr. Pećnjak i Špiljak, 2014, odjeljak 1). Međutim, tvrdilo se da je identitet u pitanju samo kontingentan (za raspravu vidi Sesardić, 1984). Da uzmemo klasičan primjer, pretpostavimo da je bol kod ljudi identična s aktivacijom C-vlakana u mozgu. Mnogima je bilo intuitivno jasno da je moguće da postoje druga bića koja su biološki drukčija od ljudi, no svejedno osjećaju bol. Na primjer, možemo zamisliti Marsovce koji nemaju C-vlakna, no svejedno osjećaju bol. Stoga ima smisla tvrditi da je Kripke smatrao potrebnim odgovoriti na pitanje kako se argument za nužnost identiteta povezuje s mogućnošću da postoje neki iskazi identiteta koji su kontingentni (usp. Burnyeat, 1979, 471).

U Kripkeovoj (1997) raspravi mogu se razlikovati tri tipa iskaza o identitetu:

a) Iskazi identiteta koji povezuju individualne opise: poput »Izumitelj bifokalnih stakla je identičan prvom upravitelju pošte Sjedinjenih Američkih Država«.

b) Iskazi identiteta koji povezuju prava imena (engl. proper name): poput »Ciceron je Tulije

c) Iskazi identiteta koji se odnose na teorijske redukcije u znanosti: poput »Bol je identična aktivaciji C-vlakana« ili »Toplina je prosječna kinetička energija«.

Kripke se slaže da moraju postojati istiniti iskazi identiteta koji su kontingentni. Te rečenice, ako su istinite, mogle bi imati formu koja je istaknuta u (a). Čini se jasnim da je izumitelj bifokalnih stakla mogla biti neka druga osoba koja nije bila prvi upravitelj pošte u Sjedinjenim Američkim Državama. Stoga se čini istinitim reći da je kontingentna činjenica da jedna te ista osoba zadovoljava oba opisa. Nadalje, Kripke 
$(1979,481)$ objašnjava da su istiniti kontingentni identiteti, u smislu (a), kompatibilni s argumentom da je identitet nužan. Kada dopustimo da je izumitelj bifokalnih stakla mogla biti osoba koja nije bila prvi upravitelj pošte u SAD-u, time ne tvrdimo da je osoba koja je zaista izumila bifokalna stakla mogla biti neka druga osoba u odnosu na prvog upravitelja pošte u SAD-u. Dapače, tvrdimo da je ta osoba bila ili jest samoidentična, no to ne implicira da je nužno da je ta osoba bila Benjamin Franklin, tj. osoba koja je zbilja izumitelj i prvi upravitelj pošte u SAD-u. Potonji opisi predstavljaju kontingentna svojstva Franklina koja služe kako bismo ga mogli identificirati. Stoga, prema Kripkeu, tipovi iskaza identiteta (a) mogu biti kontingentni te je njihovo postojanje kompatibilno s premisom (1) i konkluzijom (K).

Međutim, što se tiče tipova iskaza identiteta (b) i (c), Kripke ima drugačije gledište. Uobičajeno objašnjenje zašto bi netko smatrao da su iskazi identiteta koji koriste prava imena ili teorijske termine kontingentni, je mogućnost aposteriornog otkrića da dva prava imena ili dva teorijska termina mogu referirati na istu stvar. Na primjer, netko može znati da je Mark Twain autor Huckleberryja Finna i da je Samuel Clemens poslovni čovjek te kasnije otkriti, čitajući Twainovu biografiju, da su Mark Twain i Samuel Clemens ista osoba. Slično, netko može znati da vatra emitira toplinu i kasnije otkriti da toplina nije ništa drugo nego prosječno gibanje kinetičke energije. Na temelju ovog a posteriori otkrića, zajedno s nekada općeprihvaćenom tvrdnjom da su a posteriorni iskazi uvijek kontingentni, bilo je dosta prirodno doći do zaključka da su iskazi poput »Ciceron je Tulije« $\mathrm{i} »$ Bol je aktivacija C-vlakana« također kontingentni. Međutim, poznato je da je Kripke (1997) argumentirao da ne smijemo miješati epistemičke s metafizičkim pojmovima. Činjenica da se istinosna vrijednost nekih iskaza može spoznati a posteriori ne implicira da taj iskaz nema nužno određenu istinosnu vrijednost. Slično tome, Kripke je argumentirao da postoje istiniti $a$ priori iskazi koji su samo kontingentno istiniti te da postoje a posteriori iskazi koji su nužno istiniti.

${ }^{4}$ No, treba primijetiti da neki iskazi tipa (a) izražavaju nužan identitet. Na primjer, nužan iskaz tog tipa bio bi: »Korijen broja 4 je identičan broju $2 . \lll$ 
U vrijeme kada Kripke brani tezu da su iskazi identiteta nužni, dominirale su opisne teorije pravih imena. ${ }^{5} \mathrm{Na}$ primjer, ime »Aristotel « bi prema tim gledištima, između ostalog, značilo nešto poput »Filozof koji je živio u antičkoj Grčkoj te je bio učitelj Aleksandra Velikog«. Te teorije dopuštaju mogućnost kontingentnog identiteta. Na primjer, čini se sasvim mogućim da je neka druga osoba mogla biti učitelj Aleksandra Velikog. Stoga izgleda da je poistovjećivanje Aristotela s osobom koja je bila učitelj Aleksandra Velikog samo kontingentna činjenica.

Kako bi obranio zaključak da je identitet nužan, Kripke je morao ukazati na probleme s opisnim teorijama značenja pravih imena te razviti gledište o značenju pravih imena koje bi bilo kompatibilno s konkluzijom (K). U tu svrhu, Kripke (1997) je uveo pojam krutog označitelja. Prema Kripkeu funkcija pravih imena je jednostavno da referiraju na predmete. Međutim, predmeti mogu biti denotirani krutim i ne-krutim označiteljima. Na primjer, »Izumitelj bifokalnih stakla« označava Benjamina Franklina u našem aktualnom svijetu. Međutim, sasvim je moguće da je neka druga osoba mogla izumiti bifokalna stakla, s obzirom da biti izumitelj bifokalnih stakla nije nužno svojstvo koje pripada Benjaminu Franklinu. Stoga prema Kripkeovoj terminologiji »Izumitelj bifokalnih stakla« nije kruti označitelj jer referira na Benjamina Franklina samo kontingentno. Drugim riječima, nije kruti označitelj jer se referencija termina »Izumitelj bifokalnih stakla« mijenja kroz različite moguće svjetove.

S druge strane, pojam kruti označitelj je »termin koji označava isti predmet u svim mogućim svjetovima« (Kripke 1979, 488). S obzirom na činjenicu da je funkcija pravih imena referiranje na predmete neovisno o njihovom opisu, njihov je zadatak izdvojiti isti predmet u svim mogućim svjetovima u kojima taj predmet postoji. Kripke smatra kako se ista vrsta razmatranja može primijeniti na teorijske termine koji su prema njemu također kruti označitelji. Ako prava imena i teorijske termine tretiramo kao krute označitelje, jasno je da iskazi identiteta koji koriste takve termine ne mogu biti kontingentni jer referiraju na iste predmete u svim mogućim svjetovima u kojima postoje. Stoga, ne predstavljaju problem za premisu (1) ili konkluziju (K).

${ }^{5} \mathrm{Za}$ raspravu o pravim imenima u kontekstu logike usp. Kovač (2005, pogl. 4). Za pregled i uvod u filozofiju jezika, usp. Devitt i Sterenly (2002). 
Sažmimo dosadašnju raspravu. Kripke koristi argument prema kojemu predmeti, ukoliko su identični, moraju biti nužno identični. Kako bi otklonio filozofske nedoumice u vezi zaključka da je identitet, metafizički shvaćen, nužan, Kripke razrađuje argumente prema kojima je identitet (i) kontingentan na način koji bi bio kompatibilan s predstavljenim argumentom ili (ii) ono što smo smatrali kontingentnim identitetom se ispostavilo lažnim. Ako je (ii) slučaj, to je prema Kripkeu zato što filozofi prihvaćaju pogrešnu teoriju pravih imena i/ili su pogrešno povezali epistemičke pojmove, kao što su a posteriori/a priori s metafizičkim pojmovima kao što su kontingentno/nužno.

\section{Kontingentni identitet}

Unatoč dokazu za nužnost identiteta i Kripkeove filozofske obrane istog, zadržala se intuicija kako su neki iskazi identiteta kontingentni čak i kada se u njima koriste prava imena (za pregled rasprave vidi Schwarz, 2013). U tom pogledu, utjecajnu teoriju kontingentnog metafizičkog identiteta nudi Allan Gibbard (1975) te ćemo se njome baviti u nastavku.

Gibbard daje primjer komada gline koji ima oblik kipa. Kako bi učinio primjer što intuitivnijim, komad gline naziva Hrpić (engl. Lum$p l$ ), a kip koji je sačinjen od tog komada gline naziva Golijat. Hrpić i Golijat su ista stvar jer su u isto vrijeme počeli postojati, od tad pa nadalje su imali sva ista svojstva (na primjer, boju, oblik, lokaciju i tome slično) i prestaju postojati $u$ isto vrijeme.

»Napravim glineni kip djeteta Golijata u dva dijela, jedan dio iznad struka i drugi dio ispod struka. Jednom kad završim obje polovice, lijepim ih zajedno istovremeno dovodeći u postojanje novi komad gline i novi kip. Dan kasnije, razbijam kip, pritom istovremeno ukidajući postojanje i kipa i komada gline. Komad gline i kip su postojali tijekom identičnog vremenskog perioda.« (Gibbard, 1975, 191)

Međutim, identitet Hrpića i Golijata čini se kontingentnim jer izgleda sasvim moguće da, nakon što je kip formiran, netko ga zgnječi i pretvori u kuglu. U tom slučaju, Golijat je uništen, ali Hrpić nastavlja postojati, iako sad u drugom obliku.

Prema Gibbardu, slučaj Hrpić/Golijat pruža primjer kontingentnog identiteta koji zadovoljava sljedeći uvjet: 
(KI) $h=g \wedge \diamond(h$ postoji $\wedge g$ postoji $\wedge(h \neq g))$. (Gibbard 1975,187$)$

Hrpić i Golijat zadovoljavaju (KI) jer su oni zapravo isti predmet, ali je moguće (kao što pokazuje primjer s kuglom) da nisu identični u svakom mogućem svijetu.

Ako prihvatimo da Hrpić $=$ Golijat unatoč tome što je moguće da Hrpić $\neq$ Golijat, onda nam je potrebna alternativa Kripkeovoj teoriji pravih imena. Razlog tome jest da, ukoliko su prava imena kruti označitelji koji referiraju direktno na predmete, onda slijedi da je Hrpić različit od Golijata ili oni ipak označavaju isti predmet u svim mogućim svjetovima.

Iz tog razloga Gibbard razvija sortalnu' teoriju referencije. Prema ovom gledištu nema smisla pitati

»... što bi ta stvar bila, (...), neovisno o tome kako referiramo na nju« [jer] »(p)rava imena kao 'Golijat' ili 'Hrpić' referiraju na stvar određene vrste: 'Golijat' referira na nešto što je kip, a 'Hrpić' na nešto što je nakupina ili hrpa gline.« (Gibbard, 1975, 194-195)

Dakle, prema ovom gledištu, iskaz identiteta treba specificirati pod kojim opisom izdvajamo predmet u pitanju. Golijat referira na određeni predmet kao kip, a Hrpić referira kao nakupina gline. Kao kip, Golijat je identičan s Hrpićem. Prema ovome gledištu, pitanja identiteta kroz moguće svjetove imaju smisla samo ako ih relativiziramo kroz upotrebu sortala. Stoga, ima smisla pitati je li Hrpić ista nakupina gline kao i $x$, ali nema smisla pitati je li Hrpić kao takav ista stvar kao $x$, jer u potonjem slučaju ne karakteriziramo tu stvar na određeni način.

Nadalje, iz ove perspektive nema smisla govoriti o krutim i ne-krutim označiteljima simpliciter. Je li označitelj krut, ovisi o sortalu na koji se poziva.

》Označitelj može biti krut u odnosu na sortal: može biti kip-kruti, kao što je to Golijat, ili može biti nakupina-krut, kao što je to Hrpić. Primjerice, označitelj je kip-krut ako označuje isti kip u svakom mogućem svijetu u kojem taj kip postoji i ne označuje ništa drugo ni u jednom drugom mogućem svijetu. Posebnost pravih imena kao što su 'Golijat' ili 'Hrpić' nije u tome što su kruti označitelji, nego da su kruti s obzirom na sortal na koji se pozivaju. 'Golijat'

${ }^{6} \mathrm{Na}$ engleskom termin 'sortal' označuje opće termine za vrste stvari koji se obično izražavaju brojivim imenicama, poput imenica kojima označavamo vrste životinja, stvari i drugih pojava. 
referira na nešto što je kip, on je kip-kruti; 'Hrpić' referira na nešto što je nakupina i on je nakupina-krut.« (Gibbard, 1975, 195)

Golijat kao kip kruto označuje isti kip u svim mogućim svjetovima u kojima postoji kao kip. U aktualnom svijetu, to znači da Golijat kao kip označuje nakupinu ili hrpu gline koju nazivamo Hrpić.

Prema Gibbardovoj teoriji referencije, podrijetlo određenog predmeta upravo ga čini predmetom pod određenim opisom, tj. u ovom slučaju određuje njegov sortal. Stoga, podrijetlo Golijata kao kipa određuje na koji predmet ime »Golijat« referira. Također uvjeti trajanja (engl. persistence conditions) određuju identitet predmeta tako što definiraju njegov sortal (usp. Banfi, 2021). Na primjer, Golijat referira na kip koji je napravljen $u$ određeno vrijeme i na određenom mjestu od određenog komada gline. Kroz to vrijeme, Golijat i Hrpić referiraju na isti predmet jer im je podrijetlo isto. Međutim, kada je Golijat uništen i zgnječen $u$ oblik kugle, on prestaje postojati. Hrpić nastavlja postojati u drugom obliku te prestaje biti ista nakupina gline kao Golijat, unatoč tome što dijele zajedničko podrijetlo i što su bili ista stvar određeno vrijeme. Tome je tako jer Hrpić i Golijat imaju drukčije uvjete trajanja koji određuju njihove sortale. Hrpić može preživjeti radikalne promjene oblika, dok Golijat ne može te se u tom smislu i njihovi uvjeti trajanja razlikuju.

Gibbard dopušta da su neki iskazi identiteta nužni. Njegovo gledište može se pojasniti na primjeru Zornjače i Večernjače.' Prema Gibbardovom gledištu, Zornjača i Večernjača kruto označuju istu stvar. Drugim riječima, označuju istu stvar u svim mogućim svjetovima te je njihov identitet nužan. To slijedi zato jer se Zornjača i Večernjača pozivaju na isti sortal koji je određen istim podrijetlom i uvjetima trajanja. Štoviše, Gibbardovo gledište zadržava razliku između nužnih i a priori

${ }^{7}$ Primjer Zornjače i Večernjače u filozofsku literaturu uvodi Gotlob Frege (1995) kako bi objasnio razliku između smisla i značenja riječi. U antičko doba smatralo se da je ono što mi zovemo »Zornjača« najsjajnija zvijezda koja se pojavljuje na jutarnjem nebu te da je ona različit predmet od onoga što mi zovemo »Večernjača« što je za njih označavalo najsjajniju zvijezdu na večernjem nebu. Kasnije su antički astronomi otkrili da se zapravo radi o istom predmetu, a to je planet Venera. Dakle, Zornjača = Večernjača. Prema, Fregeu riječ »Zornjača« ima smisao koji možemo izraziti s opisom »Najsjajnija zvijezda na jutarnjem nebu«, dok riječ »Večernjača« ima drugi smisao koji možemo izraziti s opisom »Najsjajnija zvijezda na večernjem nebu«. Međutim, unatoč različitim smislovima astronomi su promatranjem ustanovili da »Zornjača« $\mathrm{i} »$ Večernjača« označuju isti predmet, planet Veneru, te $\mathrm{u}$ tom smislu imaju isto značenje (ili referenciju). 
istina jer dopušta da se identitet Zornjače i Večernjače može utvrditi $a$ posteriori, ali je istina iskaza o njihovom identitetu nužna jer se oba termina pozivaju na isti sortal.

Unatoč elegantnim rješenjima što se tiče objašnjenja kontingentnih iskaza identiteta, Gibbardova teorija susreće se s određenim izazovima. Jedan od glavnih izazova sastoji se u tome kako pomiriti istinitost Leibnizovog zakona i sortalne teorije pravih imena. U sljedećem pododjeljku bavimo se upravo tim problemom.

\subsection{Kontingentni identitet i Leibnizov zakon}

Problem sortalne teorije pravih imena jest to što naizgled krši Leibnizov zakon. Čini se da primjena Leibnizovog zakona vodi Gibbarda (usp. 1975, 200-201) u sljedeću problematičnu situaciju. Prema Gibbardu sljedeći iskazi su istiniti:

$(16) \square($ Hrpić postoji $\rightarrow($ Hrpić $=$ Hrpić $))$

(17) Golijat = Hrpić

Međutim, na temelju (16) i (17) prema Leibnizovu zakonu nerazlučivosti identiteta možemo derivirati sljedeći iskaz:

$(18) \square($ Hrpić postoji $\rightarrow($ Golijat $=$ Hrpić $))$

Međutim, (18) je u suprotnosti s tvrdnjom da je Golijat samo kontingentno identičan s Hrpićem. Postavlja se pitanje kako izbjeći prihvaćanje (18), a da se ne krši Leibnizov zakon?

Gibbardovo rješenje jest ograničiti domenu primjene Leibnizova zakona (također usp. Ben-Yami, 2018; 2020). Smatra kako je Leibnizov zakon primjenjiv na svojstva i relacije, ali ne u svim kontekstima (Gibbard, 1975, 201). Štoviše, prema Gibbardu:

»Iskazi sačinjeni od modalnih operatora, (...), ne daju svojstva konkretnih stvari, kao što su kipovi i komadi gline. Modalni iskazi se ne primjenjuju na konkretne stvari neovisno o tome kako su one označene. Hrpić jest, primjerice, ista stvar kao Golijat: radi se o glinenom kipu djeteta Golijata kojeg sam sastavio i zatim razbio. No, nužan identitet nije svojstvo kojeg stvar ima ili nema, jer nema smisla pitati je li ta stvar, kao takva, nužno identična s Hrpićem. Modalni konteksti, dakle, ne pripisuju svojstva ili relacije konkretnim stvarima te zastupnik kontingentnog identiteta može na taj način odgovoriti na Leibnizov zakon.« (Gibbard, 1975, 201-202) 
Gibbard još dodaje da Leibnizov zakon dopušta zamjenjivanje termina koji referiraju na iste stvari samo u kontekstima »koji pripisuju svojstva i relacije « (Gibbard, 1975, 201-202). Iz tvrdnje da modalni konteksti ne pripisuju svojstva ili relacije stvarima i tvrdnje da se Leibnizov zakon primjenjuje samo u kontekstima u kojima se stvarima pripisuju svojstva i relacije slijedi da se Leibnizov zakon ne primjenjuje u modalnim kontekstima. Stoga, prema Gibbardovom gledištu nije legitimno (18) derivirati iz (16) i (17) na temelju Leibnizovog zakon. Štoviše, ako je Gibbard u pravu, onda niti Kripkeov originalni argument ne bi bio valjan jer nelegitimno tretira modalni operator kao svojstvo koje stvar može posjedovati. Drugim riječima, ovakvo rješenje negira pretpostavku de re modalnosti koja je potrebna kako bi se na temelju Leibnizovog zakona derivirala premisa (2) argumenta za nužnost identiteta (usp. Ben-Yami, 2018).

Prema ovom rješenju kada govorimo o Golijatu i Hrpiću u modalnom kontekstu, onda ne referiramo direktno na njih bez obzira kako su opisani. Međutim, sada se postavlja pitanje na što točno referiramo kada govorimo o stvarima u modalnim kontekstima? U nastavku ćemo razmotriti kako Gibbard odgovara na ovo pitanje.

\subsection{Kontingentni identitet, modalni kontekst i individualni pojmovi}

Nekome tko dijeli Kripkeove intuicije može se činiti čudnim tvrdnja da u modalnim kontekstima ne referiramo direktno na konkretne stvari. No, ovakvo gledište nije čudno iz perspektive sortalne teorije pravih imena. Prema toj teoriji, kada govorimo o identitetu stvari, onda govorimo o tim stvarima pod određenim opisom. Prirodno proširenje ovog gledišta koje nudi Gibbard (1975, 204-205) u kontekstu problema s primjenom Leibnizova zakona jest tvrditi kako pri uvođenju modalnog konteksta prava imena ne referiraju na konkretne stvari nego na načine na koji su te stvari izdvojene. Posljedično, stvari nemaju de re modalna svojstva, nego imaju modalna svojstva kao stvari pod određenim opisom. Na primjer, iako ne možemo reći da Golijat nužno ima neko svojstvo simpliciter, teorija dopušta da je Golijat, recimo, nužno humanoid ili čovjekolik kao kip (Gibbard, 1975, 208). 
Gibbardova teorija prati način na koji Rudolf Carnap (1947) proširuje Fregeovu (1995) teoriju o tome kako se prava imena ponašaju u modalnim kontekstima. Prema Fregeu i Carnapu, u modalnim kontekstima imena mijenjaju referencu te se više ne odnose na predmete koje imenuju u normalnim kontekstima, već imenuju pojam ili smisao koji povezujemo s tim imenom (vidi bilješku 7). Primjerice, u iskazu

(19) Zornjača = Večernjača

izrazi »Zornjača« $\mathrm{i}$ »Večernjača« referiraju na konkretne predmete, a to je planet Venera. Međutim, $u$ iskazu

(20) $\square($ Zornjača postoji $\rightarrow($ Zornjača $=$ Večernjača $))$

referenca se mijenja te sada izraz »Zornjača« referira na pojam koji vežemo uz planet Veneru kada o njoj razmišljamo pod opisom najsjajnija zvijezda na jutarnjem nebu. Dok kada koristimo izraz » Večernjača« referiramo na pojam koji vežemo uz Veneru kada o njoj razmišljamo pod opisom najsjajnija zvijezda na noćnom nebu.

U slučaju kvantifikacije, kada je uveden modalni kontekst, Gibbard slijedi Carnapa (1947) i tvrdi kako varijable slično mijenjaju svoje vrijednosti. Tako da u modalnim kontekstima njihova domena prestaje biti skup konkretnih stvari već to postaje skup pojmova o stvarima. U skladu s tim gledištem, u otvorenoj rečenici

(21) $\diamond(\text { Hrpić postoji i }(x \neq \text { Hrpić }))^{s}$

$x$ se ne odnosi na konkretne stvari, nego na individualne pojmove. U (21) se tvrdi da je moguće da postoji pojam Hrpić te da je on različit od nekog pojma x. Formalno se individualni pojmovi shvaćaju kao funkcije koje kao argumente uzimaju moguće svjetove, a kao vrijednosti daju stvari u tim mogućim svjetovima. Drugim riječima, individualni pojam je funkcija $(f)$ čija domena je skup mogućih svjetova $(s \in S)$, a kodomena skup predmeta u tim svjetovima $(p \in P)(f: S \rightarrow P)$.

Gibbard $(1975,204-205)$ daje primjere kako varijable i predikati mijenjaju vrijednosti kada su uvedeni modalni konteksti. Uzmimo da je »E« predikat koji znači »postoji«, a »H« znači »humanoid«. Pod »humanoid« Gibbard misli na nešto što »ima oblik čovjeka kroz svoju

\footnotetext{
${ }^{8}$ Rečenica je otvorena jer varijabla $x$ u njoj nije vezana određenim kvantifikatorom.
} 
ranu povijest« (Gibbard, 1975, 204). U nemodalnom kontekstu otvorena rečenica

(22) $\mathrm{E} x \rightarrow \mathrm{H} x$

znači ako $x$ postoji, onda je $x$ humanoid i ovdje varijabla $x$ uzima kao vrijednosti konkretne stvari. Međutim, kada se uvede modalni kontekst poput

(23) $\square(\mathrm{E} x \rightarrow \mathrm{H} x)$

značenje iskaza se mijenja. Ne samo da varijabla $x$ mijenja domenu vrijednosti koja se sada odnosi na individualne pojmove nego i predikati E i H mijenjaju svoje značenje. Prema Gibbardu (1975, 204), sada E označuje »je pojam pojedinačne stvari koja postoji«, a H označuje »je pojam pojedinačne stvari koja je humanoid«. Gibbard objašnjava da je iskaz tipa (23) »istinit o bilo kojem individualnom pojmu $f$ koji za svaki mogući svijet $s$, ako $f$ dodjeljuje predmet $s$-u, tada $f$ dodjeljuje $s$-u individuu koji je humanoid u $s$-u« (Gibbard, 1975, 204). Drugim riječima, (23) je istinit o pojmu Golijat koji dodjeljuje konkretni predmet, naime kip Golijata, svakom mogućem svijetu u kojem taj kip postoji kao humanoid. S druge strane, (23) nije istinit o pojmu Hrpić jer je moguće da postoji svijet u kojem Hrpića pretvorimo u kuglu te on prestaje biti humanoid.

Ovo formalno rješenje koje se oslanja na Carnapovu (1947) semantiku za modalnu logiku, omogućava Gibbardu da ograniči primjenu Leibnizovog zakona na način da se ne obvezuje na prihvaćanje iskaza (18). Prisjetimo se, ovim iskazom se tvrdi:

$(18) \square($ Hrpić postoji $\rightarrow($ Golijat $=$ Hrpić $))$

Vidjeli smo da se prema Gibbardu ovaj iskaz ne može derivirati iz (16) i (17) na temelju Leibnizovog zakona jer se on odnosi samo na svojstva i njihove predmete u ne-modalnim kontekstima. Međutim, sada također možemo vidjeti da ovaj iskaz nije istinit. Prema Gibbardu imena »Golijat« $\mathrm{i} »$ Hrpić« ne referiraju direktno na Golijata i Hrpića nego na pojam Golijata i pojam Hrpića. Međutim, pojam Golijat označuje različiti individualni pojam od onog koji označuje pojam Hrpić. Kako smo ranije vidjeli, rečenica (23) je istinita o pojmu Golijat, u smislu da označuje funkciju koja u svim mogućim svjetovima u kojima 
dodjeljuje neki predmet dodjeljuje predmet koji je humanoid. Međutim, (23) nije istinit o pojmu Hrpić koji ima drukčije uvjete trajanja od Golijata. Takvim se rješenjem ostavlja prostor za postojanje kontingentno istinitih iskaza identiteta. Naime, ako je iskaz »Hrpić = Golijat « istinit, on je samo kontingentno istinit jer postoji mogući svijet kojem pojmovi Hrpić i Golijat dodjeljuju različite predmete.

\section{Zaključak}

U prvom dijelu rada dali smo formalni prikaz Kripkeovog dokaza za nužnost identiteta te smo dali pregled filozofske pozadine na temelju koje je dokaz osmišljen. Unatoč utjecaju Kripkeovog dokaza i argumenata koje je nudio u prilog tezi o nužnosti identiteta, neki autori i dalje nastoje opravdati suprotno gledište prema kojemu stvari mogu biti kontingentno identične. Stoga smo se u drugom dijelu rada bavili Gibbardovim utjecajnim odgovorom na pitanje kako bi se mogla sačuvati ideja da nisu svi metafizički iskazi identiteta nužni. Vidjeli smo da Gibbardovo rješenje dolazi s određenim teorijskim izazovima. Ono zahtijeva da se modalni konteksti tretiraju na poseban način te vodi prema ideji da naš govor o identitetu stvari u modalnim kontekstima ne označuje konkretne stvari, već stvari kako ih zahvaćamo našim pojmovnim aparatom.

Zaključno možemo reći da nam, s jedne strane, Kripke omogućuje da u modalnim kontekstima govorimo o stvarima kakve one jesu i da spekuliramo o njihovoj ultimativnoj prirodi, tj. koja bi bila njihova esencijalna ili nužna svojstva. S druge strane, ako je Gibbard u pravu, onda zapravo ne možemo spekulirati o metafizičkoj prirodi stvari ili njihovim nužnim svojstvima jer prelaženjem u modalne kontekste prestajemo govoriti o stvarima u standardnom smislu te riječi i počinjemo govoriti o pojmovima kojima referiramo na stvari. Vrijedi li prihvatiti ovakvo gledište kako bi se spasila intuicija da neki identiteti mogu biti kontingentni, ostavljamo kao otvorenu raspravu za drugu priliku. 


\section{Literatura}

Barcan, Ruth C. (1947), »Identity of individuals in a strict functional calculus of second order«, The Journal of Symbolic Logic, 12(1), str. 12-15.

Banfi, Luca (2021), »Is there change on the B-theory of time?«, European Journal of Analytic Philosophy, 17(1), str. (B1)5-28. https://doi.org/10.31820/ ejap.17.1.7

Ben-Yami, Hanoch (2018), »The logical contingency of identity«, European Journal of Analytic Philosophy, 14(2), str. 5-10.

Ben-Yami, Hanoch (2020), »The Barcan formulas and necessary existence: The view from Quarc«, Synthese. https://doi.org/10.1007/s11229-020-02771-4

Berčić, Boran (2012), Filozofija, sv. 2, Zagreb: Ibis Grafika.

Berčić, Boran (ur.) (2017), Perspectives on the Self, Rijeka: University of Rijeka.

Burgess, John P. (2014), »On a derivation of the necessity of identity«, Synthese, 191(7), str. 1567-1585.

Burnyeat, Myles (1979), »Introduction to Saul Kripke: Identity and individuation«, u: Burnyeat, Myles i Honderich, Ted (ur.), Philosophy as It Is, London: Penguin books, str. 467-477.

Carnap, Rudolf (1947), Meaning and Necessity: A Study in Semantics and Modal Logic, Chicago: University of Chicago Press.

Descartes, René (2015), Meditacije o prvoj filozofiji, preveo Josip Talanga, Zagreb: KruZak.

Devitt, Michael i Sterelny, Kim (2002), Jezik i stvarnost: Uvod u filozofiju jezika, preveo Boran Berčić, Zagreb: KruZak.

Frege, Gottlob (1995), Osnove aritmetike i drugi spisi, preveli Filip Grgić i Maja Hudoletnjak Grgić, Zagreb: KruZak.

Gibbard, Allan (1975), »Contingent identity«, Journal of Philosophical Logic, 4(2), str. 187-222. https://doi.org/10.1007/BF00693273

Kovač, Srećko (2005), Logičko-filozofijski ogledi, Zagreb: Hrvatsko filozofsko društvo.

Kripke, Saul (1971), »Identity and necessity«, u: Munitz, Milton K. (ur.), Identity and Individuation, New York: New York University Press, str. 135-164.

Kripke, Saul (1979), »Identity and necessity«, u: Honderich, Ted i Burnyeat, Myles (ur.), Philosophy as It Is, London: Penguin Books ltd., str. 476-513.

Kripke, Saul (1987) »Istovjetnost i nužnost«, u: Miščević, Nenad i Potrč, Matjaž (ur.), Kontekst i značenje, Rijeka: Izdavački centar Rijeka, str. 113-149.

Kripke, Saul (1997), Imenovanje i nužnost, preveo Tomislav Ogrinšak, Zagreb: KruZak.

Lowe, Ernest J. (2002), A Survey of Metaphysics, Oxford and New York: Oxford University Press. 
Magidor, Ofra (2011), »Arguments by Leibniz’s Law in metaphysics«, Philosophy Compass 6(3), str. 180-195. https://doi.org/10.1111/j.17479991.2010.00379.x

Noonan, Harold i Curtis, Ben (2018), »Identity«, u: Zalta, Edward N. (ur.), The Stanford Encyclopedia of Philosophy, ljeto 2018. Metaphysics Research Lab, Stanford University. Dostupno na: https://plato.stanford.edu/archives/ sum2018/entries/identity/

Pećnjak, Davor i Janović, Tomislav (2016), Prema dualizmu: Ogledi iz filozofije uma, Zagreb: Ibis Grafika.

Pećnjak, Davor i Špiljak, Ivan (2014), »Argument iz znanja i modalni argument za dualizam u filozofiji uma«, Bogoslovska smotra, 84(1), str. 73-95.

Quine, Willard van Orman (1961), »Reference and modality«, u: Quine, W.v.O., From a Logical Point of View, New York: Harper and Row, str. 139-159.

Schwarz, Wolfgang (2013), »Contingent identity«, Philosophy Compass, 8(5), str. 486-495. https://doi.org/10.1111/phc3.12028.

Sesardić, Neven (1984), Fizikalizam, Beograd: Istraživačko-izdavački centar SSO Srbije.

Wiggins, David (1965), »Identity statements«, u: Butler, Ronald J. (ur.), Analytic Philosophy: Second Series, Oxford: Basil Blackwell, str. 40-71.

Williamson, Timothy (2013), Modal Logic as Metaphysics, Oxford: Oxford University Press.

\section{MUST IDENTITY BE NECESSARY?}

\section{Marko Jurjako, Zdenka Brzović}

In the paper, we offer an overview of the context within which the well-known proof of the necessity of identity is formulated. A formal account of this proof is presented as formulated by the renowned philosopher and logician Saul Kripke. Furthermore, we discuss the account of the philosopher Allan Gibbard, who defends the claim that some statements of identity can be contingent. The main goal of the paper is to acquaint the readers who understand the Croatian language with the formal aspect of the discussion on the necessity of identity and to give a brief overview of the context within which the arguments for the necessity of identity are formulated.

Keywords: Allan Gibbard, proof of the necessity of identity, contingent identity, numerical identity, Saul Kripke 